\title{
Biochemical analysis of the metabolism of small rodents living in different radioecological conditions
}

\author{
Natalґya A. Orekhova \& Larisa N. Rasina
}

\begin{abstract}
The initial differences of metabolism and their modification under the conditions of radioactive pollution of the environment are presented on the basis of the complex of biochemical parameters of two ecologically different species of small rodents (Apodemus uralensis and Myodes rutilus). The strategies of physiological adaptation of the studied species to radiation were determined as well as the dependence of their realization on functionally-metabolic peculiarity of the species was established.
\end{abstract}

KEY WORDS: small rodents, the EURT area, functional-metabolic changes, strategies of physiological adaptation.

Natal'ya A. Orekhova [orehova@ios.uran.ru] and Larisa N. Rasina [rasina@ios.uran.ru], Institute of Plant and Animal Ecology, Ural Branch of the Russian Academy of Sciences, 8 Marta street 202, Ekaterinburg 620144, Russia; Larisa N. Rasina [rasina@ios.uran.ru], Institute of Organic Synthesis, Ural Branch of the Russian Academy of Sciences, S. Kovalevskoi / Akademicheskaya street 20/22, Ekaterinburg, Russia.

\section{Биохимический анализ метаболизма мелких грызунов при их обитании в различных радиоэкологических условиях}

\author{
Н.А. Орехова, Л.Н. Расина
}

\begin{abstract}
РЕЗЮМЕ. По комплексу биохимических показателей у двух экологически различающихся видов мелких грызунов (малая лесная мышь Apodemus uralensis и красная полевка Myodes rutilus) представлены исходные метаболические различия и степень их модификации в условиях радиоактивного загрязнения среды обитания. Определены стратегии физиологической адаптации к радиационному фактору и установлена зависимость их реализации от исходных функционально-метаболических особенностей видов.
\end{abstract}

КЛЮЧЕВЫЕ СЛОВА: мелкие грызуны, зона ВУРСа, функционально-метаболические изменения, стратегии физиологической адаптации.

\section{Introduction}

Biochemical methods, along with commonly used hematological and immunological methods are highly sensitive to functional-metabolic shifts in the organisms of animals from natural populations in conditions of environmental pollution (Vosylienë, 1999; GadzalaKopciuch et al., 2004; Kudyasheva et al., 2004; Banni et al., 2005; Koval'chuk, 2008). Small rodents are often used as the model objects for environmental radioactive contamination indication, due to their close contact with the soil and vegetative cover containing radioactive elements (Sokolov et al., 1989). The short lifespan of small rodents together with their high reproductive rate, allow one to study remote biological consequences of a radioactive contamination of ecosystems (Vasil'ev, 2005). The studies on rodents allow to solve many issues of anthropocentric monitoring, due to the possible data extrapolation on human (Zakharov \& Clarke, 1993).

The Eastern Ural Radioactive Trace (EURT) is a research polygon for a wide range of radioecological studies (Aleksakhin \& Prister, 2008). The EURT was formed in 1957 as a result of waste container explosion at the "Mayak", when 740 PBq of radioactive substances, including long-lived radionuclides, were thrown out in the environment (Nikipelov et al., 1989). The population of mammals, living in this area, is of particular interest because it makes possible to identify mechanisms allowing them to live under the conditions of radiogenic contamination, as well as to reveal the variability of biological effects. The study of ecologically different species of rodents allows us to analyze effects of chronic exposure and radioadaptation mechanisms in dependence on physiological and metabolic features of the species.

\section{Material and methods}

The materials were collected within the EURT area $\left(55^{\circ} 46^{\prime} \mathrm{N}, 60^{\circ} 52^{\prime} \mathrm{E}\right)$ and in the adjacent (control) territory $\left(55^{\circ} 48^{\prime} \mathrm{N}, 60^{\circ} 00^{\prime} \mathrm{E}\right)$, located in $10 \mathrm{~km}$ from the central axis of the EURT area. Since 1991 the contribution of ${ }^{90} \mathrm{Sr}$ into the radionuclide contamination of the 
Table 1. Ecological characteristics of two species of small rodents (according to Gromov \& Erbaeva, 1995; Pavlinov, 2003; Grigorkina, 2004; Starichenko, 2004; Ivanter, 2008; Panteleyev, 2010).

\begin{tabular}{|l|c|c|}
\hline \multirow{2}{*}{ Ecological characteristics } & \multicolumn{2}{|c|}{ Species of rodents } \\
\cline { 2 - 3 } & Apodemus uralensis & Myodes rutilus \\
\hline Habitat area & $\begin{array}{c}\text { Broad-leaved forest and steppe } \\
\text { regions of the South-Western Eurasia } \\
\text { Seeds of woody and herbaceous } \\
\text { plants }\end{array}$ & $\begin{array}{c}\text { Boreal coniferous forest and open boreal } \\
\text { woodland of Northern Eurasia and America }\end{array}$ \\
\hline Food preferences & $\begin{array}{c}7.0 \pm 0.4 \mathrm{~Gy} \\
\text { Vegtative parts of herbaceous plants, mosses, } \\
\text { lichens, mushrooms }\end{array}$ & $12.8 \pm 0.4 \mathrm{~Gy}$ \\
\hline $\begin{array}{l}\text { Radiosensitivity (LD } 50 / 30 \text { of } \\
{ }^{137} \mathrm{Cs} \text { external } \gamma \text {-radiation) }\end{array}$ & $161 \pm 29 \mathrm{~Bq} / \mathrm{g}$ of wet bone tissue \\
\hline $\begin{array}{l}90 \mathrm{Sr} \text { concentration in animals } \\
\text { from the EURT area }\end{array}$ & $288 \pm 99 \mathrm{~Bq} / \mathrm{g}$ of wet bone tissue \\
\hline
\end{tabular}

EURT is $99.3 \%$ (Bol'shakov, 1990). The density of soil contamination with ${ }^{90} \mathrm{Sr}$ in the EURT area varies from 6.7 to $16.7 \mathrm{MBq} / \mathrm{m}^{2}\left(182-451 \mathrm{Ci} / \mathrm{km}^{2}\right)$, in the control territory - up to $0.044 \mathrm{MBq} / \mathrm{m}^{2}$ (Pozolotina et al., 2008).

The objects of our study were Apodemus uralensis Pallas, 1811 and Myodes rutilus Pallas, 1779, which are terrestrial species of small rodents with high rates of growth, senescence and reproduction, as well as relatively short lifespan. These two species were selected as objects of the study due to their different ecological and trophic preferences (Tab. 1). The differences in the radiosensitivity of these species, as well as the differences in the ${ }^{90} \mathrm{Sr}$ concentration in the bones of animals living within the EURT are presented in Tab. 1.

Animals were trapped during 2002-2008 years in accordance with generally accepted methods (Karaseva $\&$ Telitsina, 1996) in the same autumn period (September-October), which exclude the possibility of influence of seasonal variability of metabolism on the study results.

The complex of exterior, odontometric and craniometric features was used in order to identify the species (Gromov \& Erbaeva, 1995).

The sample of 105 individuals of $A$. uralensis (50 of which were captured within the EURT area, 55 - in the control territory) and 34 individuals of $M$. rutilus (11 - in the EURT, 24 - in the control territory) was used for this study. The sample includes immature yearlings with an age of 2-4 months. The age was assessed using the generative and dental systems (Kolcheva, 1986; Olenev, 2002).

The four samples (two species from two territories) used in comparison were balanced in sexual composition and year of trapping: the proportions of males and females in these samples did not differ significantly $(p=0.81)$, more than $60 \%$ of the individuals in the samples were caught during 2005-2006.

The functional-metabolic status of cells, organs and whole body of rodents was studied using the biochemical methods. The following 30 parameters of carbohydrate metabolism, lipometabolism, aerobic energy metabolism, functional activity of genome cells and proteometabolism were chosen: a) liver glycogen content, glucose concentration in blood plasma, glucosephosphate isomerase activity of erythrocytes in peripheral blood;

b) concentration of total lipids and products of lipid peroxidation (LPO) reacting with thiobarbituric acid TBA-reactive substances (TBARS) in liver, adrenals, myocardium and plasma peripheral blood;

c) cytochrome c oxidase activity in mitochondria of liver, myocardium and brain;

d) ratios of DNA concentration to protein concentration (DNA/total protein) and ratios of total RNA concentration to DNA concentration (RNA/DNA) in spleen, liver and brain;

e) total protein content of liver, adrenals, myocardium, brain and spleen, mitochondrial protein content of liver, myocardium and brain.

The animals were weighed and decapitated. The blood was collected into tubes with $5 \%$ solution of sodium citrate; plasma and erythrocytes were obtained by centrifugation at $1000 \mathrm{~g}$ during 15-20 min (Zolotnitskaya, 1987). The organs were weighed, homogenized in the tris- $\mathrm{HCl}$ buffer solution $(0.025 \mathrm{~mol} / 1, \mathrm{pH}$ 7.4) containing $0.175 \mathrm{~mol} / 1 \mathrm{KCl}$ (Romanova \& Stal'naya, 1977). The tissue homogenate was subjected to alkaline hydrolysis followed by hydrolyzate with ethanol treatment in order to extract glycogen (Davidson \& Berliner, 1974). The extraction of total lipids and protein from tissue was performed according to (Folch et al., 1975). The protein was treated by sulfuric acid to obtain inorganic nitrogen compounds (Asatiani, 1956). TBARS was obtained from tissue homogenate after its processing with $17 \%$ trichloroacetic acid solution (Stal'naya \& Garishvili, 1977). Nucleic acids (DNA, RNA) were extracted from tissue homogenate by precipitation with perchloric acid $(0.3 \mathrm{~mol} / \mathrm{l})$. Consistently, RNA were extracted from the precipitation by alkaline hydrolysis of potassium hydroxide $(0.3 \mathrm{~mol} / \mathrm{l})$, DNA - by acid hydrolysis with perchloric acid (0.5 mol/1) (Trudolyubova, 1977).

Quantitative determination was performed using the different colorimetric and spectrophotometric methods. The activity of glucosephosphate isomerase was measured on the colored reaction of fructose-6-phosphate with resorcinol (Korovkin, 1965); glucose con- 
Table 2. The biochemical parameters of rodents trapped in the control territory (differences between samples' mean values are significant at $\mathrm{p}<0.01$ ).

\begin{tabular}{|l|c|c|c|}
\hline \multirow{2}{*}{ Parameter, unit of measurement } & \multirow{2}{*}{ Organ/cells } & \multicolumn{2}{|c|}{ Species of rodents } \\
\cline { 3 - 4 } & & Apodemus uralensis & Myodes rutilus \\
\hline Total lipids content, mkg/g body & & $906.4 \pm 44.6$ & $604.2 \pm 46.5$ \\
\hline Glycogen content, mkg/g of body & Liver & $3989.3 \pm 123.1$ & $2855.6 \pm 172.9$ \\
\hline \multirow{2}{*}{ TBARS concentration, nmol/g wet } & & $18.3 \pm 1.2$ & $38.1 \pm 2.3$ \\
tissue & Liver & $39.2 \pm 1.9$ & $110.1 \pm 7.7$ \\
\cline { 3 - 4 } Glucosephosphate isomerase & Myocardium & $453.7 \pm 35.3$ & $756.5 \pm 19.3$ \\
activity, nmol/min/ml blood & Adrenals & $419.6 \pm 16.7$ & $680.7 \pm 59.7$ \\
\hline & Erythrocytes & $8857.4 \pm 159.5$ & $7028.2 \pm 698.8$ \\
Total protein content, mkg/g body & Liver & $1139.3 \pm 46.8$ & $791.4 \pm 18.7$ \\
& Myocardium & $123.2 \pm 4.1$ & $65.7 \pm 3.8$ \\
\hline \multirow{2}{*}{ Mitochondrial protein content, } & Adrenals & $2259.6 \pm 43.3$ & $1817.3 \pm 69.2$ \\
mkg/g body & Brain & $503.9 \pm 30.3$ & $366.5 \pm 21.1$ \\
\hline \multirow{2}{*}{ Cytochrome $c$ oxidase activity, } & Spleen & $675.4 \pm 26.5$ & $477.8 \pm 22.8$ \\
nmol/min./mg mitochondrial protein & Liver & $111.7 \pm 4.3$ & $81.7 \pm 8.1$ \\
& Myocardium & $144.8 \pm 4.5$ & $74.1 \pm 5.4$ \\
\hline
\end{tabular}

tent was determined using the standard sample of glucose oxidase from the "VITAL DIAGNOSTICS" collection (Russia); TBARS was determined by measuring the optical density at $532 \mathrm{~nm}$ of colored complex formed by reaction of LPO products with 2-thiobarbituric acid (Stal'naya \& Garishvili, 1977); total lipids measured on the colored reaction with vanillin $(10 \mathrm{mmol} / \mathrm{l})$ from the "LACHEMA" collection (Czech Republic); total tissue protein measured on the colored reaction of inorganic nitrogen with reagent Nessler (Pokrovskii \& Malakhova, 1969); nucleic acids were determined by measuring the optical density of hydrolysates of tissue at $270 \mathrm{~nm}$ and $290 \mathrm{~nm}$ (Spirin, 1958).

Mitochondrial fractions were extracted by differential centrifugation of tissue homogenate (Romanova \& Stal'naya, 1977). The protein content in the mitochondrial fraction was calculated according to (Bradford, 1976); the activity of cytochrome oxidase was calculated according to the Krivchenkova's method (Krivchenkova, 1977).

The absence of statistically significant $(p>0.05)$ differences in the sex ratio and year of trapping ratio in the studied samples were tested using Kruskal-Wallis test (Kruskal \& Wallis, 1952). Differences between two sample mean values were evaluated using Student's Ttest, after the checking of distribution normality hypothesis with the Shapiro-Wilks's test (Borovikov, 2003). Multivariate analysis was performed using forward stepwise discriminant analysis. The significance of the discriminant canonical function (DCF) was assessed using Chi-square test of successive roots $\left(\chi^{2}\right)$. The percent of explained variance was calculated (Kim et al., 1998) for statistically significant DCFs. The interpretation of DCF was carried out in the module of one-way analysis of variance (ANOVA) with two factors (belonging to the trapping areas and belonging to the species) used. Cluster analysis of four samples of $A$. uralensis and $M$. rutilus was performed on the basis of Mahalanobis distances, with correction on different sample size (Marcus, 1993) using UPGMA algorithm (Sneath \& Sokal, 1973). The calculations were performed in the STATISTICA v. 8.0 and STATGRAPHICS v. 8.0 software packages.

\section{Results}

The initial biochemical parameters of the two species are presented in Tab. 2.

The decrease of the concentration of glucose in the blood plasma and increase of the activity of glucosephosphate isomerase of erythrocytes were found in both species within the EURT area, whereas liver glycogen content was unchanged in $A$. uralensis, and was reduced in $M$. rutilus (Fig. 1).

The increase of the concentrations of total lipids in the liver and adrenals was found in both species within the EURT area, whereas concentrations of total lipids in blood plasma was decreased in M. rutilus and was increased in $A$. uralensis. In addition, the concentration of total lipids is decreased in A. uralensis and is increased in $M$. rutilus. The increase of the TBARS concentration in the liver, adrenals and myocardium was found in A. uralensis, the decrease - in M. rutilus (Fig. 2).

In the mitochondria of liver, brain and myocardium of $A$. uralensis within the EURT area an increase in cytochrome c oxidase activity was found, the decrease in M. rutilus (Fig. 3). 


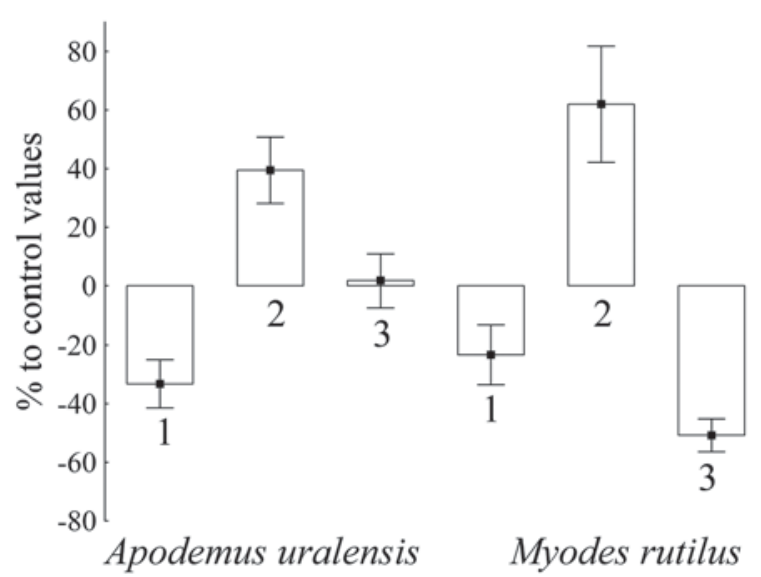

Figure 1. Changes of biochemical parameters of carbohydrate metabolism in rodents within the EURT area $(1-$ glucose concentration in blood plasma; 2 - glucosephosphate isomerase activity of erythrocytes; 3 - liver glycogen content). Percentage change $\left[\left(\mathrm{M}_{\mathrm{EURT}} / \mathrm{M}_{\text {control }}-1\right) \times 100\right.$, where $\mathrm{M}$ is a mean values] and its $95 \%$ confidence interval are shown.

- total lipids concentration - TBARS concentration

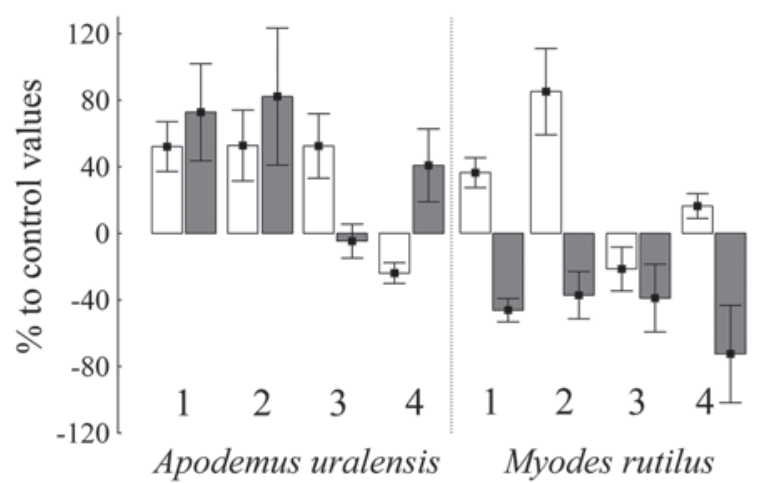

Figure 2. Changes of biochemical parameters of lipometabolism in rodents within the EURT area $(1$ - liver; 2 adrenals; 3 - plasma blood; 4 - myocardium). Percentage change and its confidence interval are shown as in Fig. 1.

The decrease of DNA/total protein ratio and increase of RNA/DNA ratio in the liver, spleen and brain were found in A. uralensis within the EURT area, whereas the opposite changes in these parameters - in M. rutilus (Fig. 4).

The slight increase of total protein content of liver, adrenals, myocardium and brain was found in A. uralensis, whereas total protein content of spleen was decreased. The increase of total protein content is more pronounced and is observed in all investigated organs in M. rutilus (Fig. 5).

The position of the samples in the space of two discriminant canonical scores is shown in Fig. 6. The first discriminant canonical function (DCF1) variability explains $79 \%$ of intergroup differences, the DCF 2 -

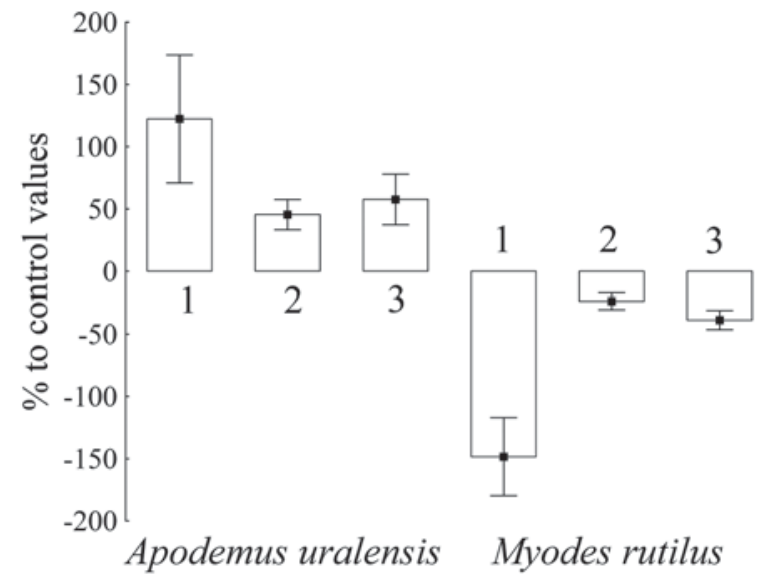

Figure 3. Change of cytochrome $c$ oxidase activity in mitochondria of liver (1), myocardium (2), brain (3) at rodents within the EURT area. Percentage change and its confidence interval are shown as in Fig. 1.

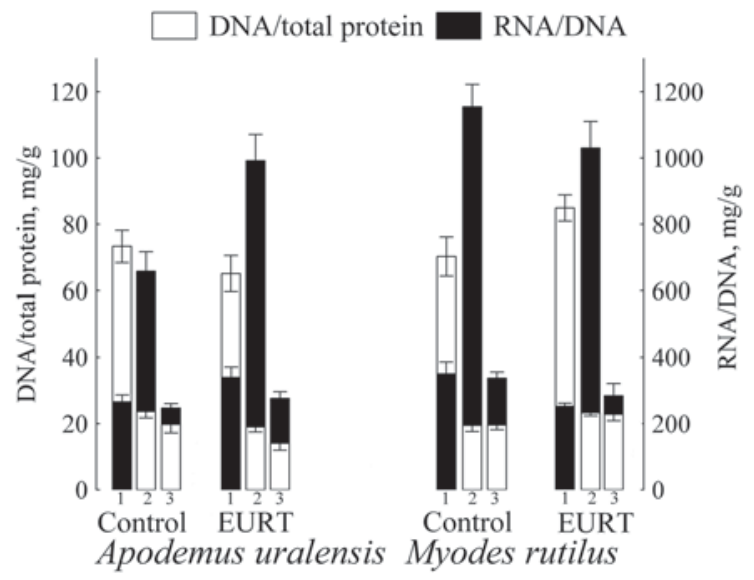

Figure 4. DNA/total protein and RNA/DNA ratios in spleen (1), liver (2), brain (3) of rodents trapped in the EURT area and control territory. The differences in all parameters are significant at $p<0.05$.

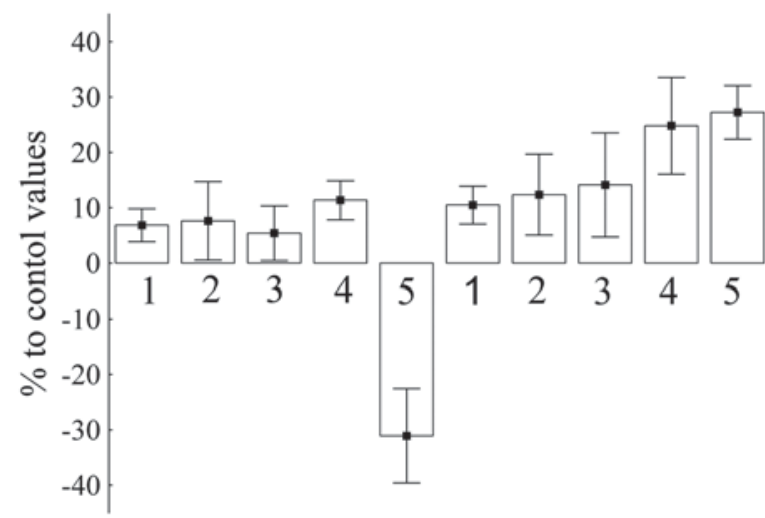

\section{Apodemus uralensis Myodes rutilus}

Figure 5. Change of total protein content of multiple rodent organs within the EURT area $(1$ - liver; 2 - myocardium; 3 - brain; 4 - adrenals; 5 - spleen). Percentage change and its confidence interval are shown as in Fig. 1. 


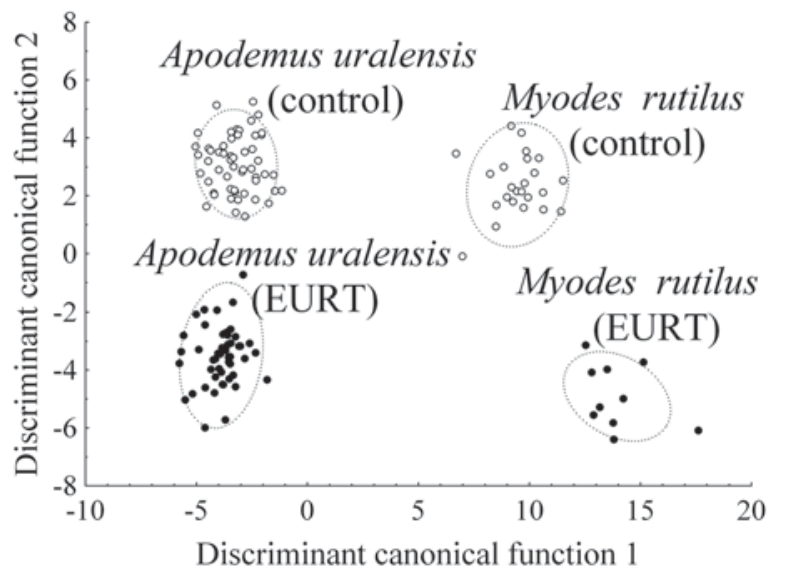

Figure 6. The position of rodent samples in the space of two discriminant canonical scores. $95 \%$ ellipsoids are shown.

$20 \%$. Analysis of variance shows the significant difference of DCF1 values between species $(F=1164.0$; $p<0.01)$ and absence of such difference between trapping areas $(\mathrm{F}=2.9 ; p<0.1)$. The $\mathrm{DCF} 2$ values reflect the difference in trapping areas $(\mathrm{F}=157.6 ; p<0.01)$ and do not depend on the species belonging $(\mathrm{F}=0.2 ; p<0.7)$.

An analysis of the Mahalanobis distances $\left(\mathrm{D}^{2}\right)$ matrix showed the maximal similarity of two samples of A. uralensis (Fig. 7). The distance between the control-EURT samples at $M$. rutilus is bigger than in $A$. uralensis.

\section{Discussion}

The comparative analysis of initial biochemical parameters in two species trapped in the control territory

The initial metabolic state of ecologically different rodents can be resulted from evolutionary adaptation to specific conditions of their habitat. At same time, it is a determinant of homeostatic reactions under an influence of new disturbing factors (Slonim, 1971; Bol'shakov, 1972; Bol'shakov et al., 1984; Koval'chuk \& Yastrebov, 2003; Mazina, 2005). For this purpose a comparative analysis of initial biochemical parameters of two species trapped in the control territory outside the zone of radioactive contamination was performed.

A. uralensis has a higher content of glycogen and total lipids of the liver (Tab. 2), which is indicative of a higher level of metabolic reserves of the organism in comparison with $M$. rutilus. The higher level of reserves in $A$. uralensis is caused by a reduced metabolic requirement for the body of this species in lipid and carbohydrate substrates of oxidation. This issue is determined by the lower level of oxidative metabolism in tissues on the basis of low values of LPO products (TBARS) in liver, myocardium, adrenals, glucosephosphate isomerase activity of erythrocytes, in comparison

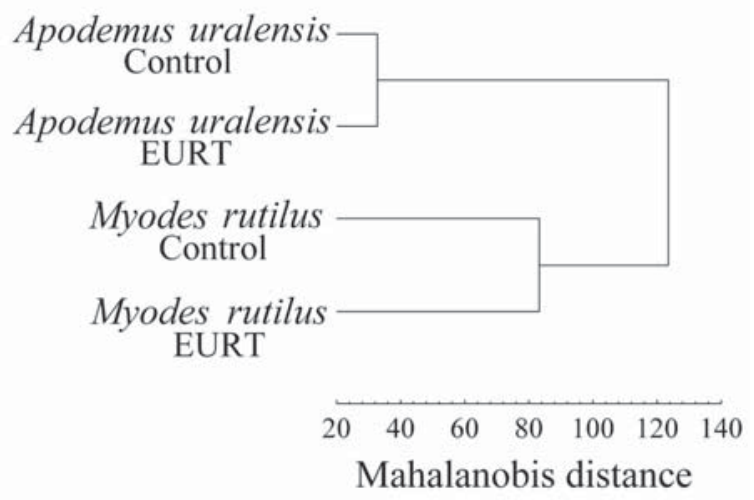

Figure 7. Biochemical similarity of four rodent samples.

with $M$. rutilus (Tab. 2). In addition to these peculiarities, A. uralensis has higher content of total protein in liver, adrenals, myocardium, brain and spleen. The same is true for the mitochondrial protein extracted from the liver, myocardium and brain (Tab. 2). This allows to reveal a higher level of the protein-synthesizing processes in the body of this species, in comparison with $M$. rutilus. The aerobic energetic metabolism in a body of $A$. uralensis is supported mainly by high content of mitochondria (mitochondrial protein content, $\mathrm{mkg} / \mathrm{g}$ body: Tab. 2), whereas the specific respiratory activities of mitochondria are low (cytochrome c oxidase activity, $\mathrm{nmol} / \mathrm{min} . / \mathrm{mg}$ mitochondrial protein: Tab. 2 ), compared with that of $M$. rutilus. Thus, the high level of tissue proteins, carbohydrate and lipid reserves in the organism and the relatively low intensity of oxidative processes in A. uralensis indicate low intensity in the functioning of cells and tissues, in comparison with $M$. rutilus.

The higher metabolic requirement of oxidation substrates in M. rutilus is the reason of a lower content of glycogen and total lipids of the liver, higher values of LPO products (TBARS) in liver, myocardium, adrenals, glucosephosphate isomerase activity of erythrocytes, in comparison with A. uralensis (Tab. 2). Aerobic energetic metabolism in $M$. rutilus is supported primarily by respiratory activity of mitochondria (cytochrome c oxidase activity, nmol/min./mg of mitochondrial protein: Tab. 2) under the low saturation of body by mitochondria (mitochondrial protein content, $\mathrm{mkg} / \mathrm{g}$ of body: Tab. 2). M. rutilus has a lower content of total protein in the liver, adrenals, myocardium, brain and spleen (Tab. 2 ), in comparison with A. uralensis. Thus, the low levels of tissue protein, carbohydrate and lipid reserves in the organism and the relatively high intensity of oxidative processes in M. rutilus indicate higher intensity in the functioning of cells and tissues, in comparison with $A$. uralensis.

These functional-metabolic characteristics of $M$. rutilus as a species, living in boreal coniferous forest 
and open boreal woodland of Northern Eurasia and America (Tab. 1) can be considered as a sign of evolutionarily adaptation to such conditions, which require an intensification of the metabolism of cells and their functions without the involvement of "expensive" protein-synthesizing processes (Koval' chuk \& Yastrebov, 2003; Panin, 2010).

The changes of biochemical parameters in rodents within the EURT area

The biochemical changes in $A$. uralensis within the EURT area (Fig. 1) are the evidence of the simultaneous activation of glycolysis and gluconeogenesis, which is the typical response of the irradiated organism (Kendysh \& Fedotov, 1967; Streffer, 1969; Ahlers, 1994). In this case, activation of glycolysis is the basis for increasing of functional activity of cells and organs, primarily of carbohydrate-dependent (erythrocytes and brain) ones, whereas gluconeogenesis provides the restoration of liver glycogen as an energy reserves under excessive functional stress on the organism (Colin, 1997).

The increase of the concentrations of total lipids and TBARS in the liver, adrenals and blood plasma (Fig. 2), indicates the activation of lipid synthesis as well as their oxidative degradation. At that, the TBARS concentration changes were more expressed, indicating the increase of the proportion of lipids in oxidative metabolism of tissue. According to the studies (Nakamura et al., 1966; Oregovic et al., 1975; Neely \& Morgan, 1974; Hershos \& Vogel, 1989; Osmundsen et al., 1991), oxidative metabolism of lipids provides many functions of the organs, including steroidogenic in adrenals, lipoprotein-synthesizing in liver, contractile in myocardium. The changes we observed in lipid metabolism of $A$. uralensis within the EURT area may be associated with activation of these functions in conditions of chronic exposure.

An increase of cytochrome c oxidase activity in the mitochondria of liver, brain and myocardium of $A$. uralensis within the EURT area (Fig. 3) indicates an increase of oxidative ATP synthesis in the cells. These changes contribute to activation of their functional activity. The decrease of DNA/total protein ratio and increase of RNA/DNA ratio in the liver, spleen and brain (Fig. 4) are the evidences of limitation of proliferation and increase of differentiation (maturity) of the cells, contributing to activation of tissue-specific functions (Brodsky \& Uryvaeva, 1985).

The slight increase of total protein content of liver, adrenals, myocardium and brain (Fig. 5), together with big level of cytochrome c oxidase activation in mitochondria (Fig. 3) is probably determined by predominant expenditure of energy for functional activity, but not by protein-synthesizing processes that is typical for the intense work of physiological systems (Meerson, 1963). A decrease of total protein content of the spleen (Fig. 5) may be caused by an activation of the catabo- lism of protein structures or reduction of mitotic activity of spleenocytes, which is characteristic for stress (Streffer, 1969; Fedotov \& Pozdnyakov, 1986; Aguas et al., 1999; Kirillov \& Smorodchenko, 1999).

So, the existence of $A$. uralensis within the EURT area leads to activation of oxidative processes, increase the level of aerobic energy metabolism with predominant expenditure of energy for amplification functioning of the cells and tissues, but not for protein-synthesizing processes.

The reaction of $M$. rutilus on the existence within the EURT is the contrary to the A. uralensis reaction. The decrease of the proportion of lipids in oxidative metabolism of tissues (increase of the total lipids concentrations on the background of decrease of the TBARS concentrations: Fig. 2), reduction of aerobic energy metabolism in mitochondria (decrease of cytochrome c oxidase activity: Fig. 3) and decrease of the degree of differentiation (maturity) of the cells (decrease of RNA/ DNA ratio: Fig. 4) were established. These changes are directed to the limiting of the expression of tissuespecific functions. Stimulation of protein-synthesizing processes in M. rutilus is more expressed (Fig. 5), compared with $A$. uralensis, due to the activation of autocatalytic function of the genome (an increase in DNA/total protein ratio: Fig. 4), underlying of proliferation and polyploidy of cells. Taking into account the intensive use of carbohydrate reserves in a body (a decrease in liver glycogen content: Fig. 1) and low levels of aerobic energy metabolism (Fig. 3), one can assume that an anaerobic glycolysis is predominant in the M. rutilus within the EURT area. This glycolysis is a source of intermediate compounds for synthesis of structural proteins and organization of proliferative processes (Guppy et al., 1993; Evtodienko \& Teplova, 1996). So, the existence of M. rutilus within the EURT area leads to reduction of oxidative processes, decrease the level of aerobic energy metabolism with predominant expenditure of energy for protein-synthesizing processes, but not for functioning of the cells and tissues.

The ideas of non-specific reactions of an organism and populations of mammals to the extreme factors of both natural and anthropogenic origin are proposed in the previous studies (Vasil'ev \& Vasil'eva, 2000; Bezel, 2006; Bol'shakov \& Moiseenko, 2009). According to the studies (Grigor'ev, 1991; Gorban \& Baraboi, 1999; Darenskaya \& Korotkevich, 2001; Grigoriev et al., 2003; Ushakov et al., 2007), ionizing radiation in a wide range of doses initiates the changes of physiological systems which are similar to symptoms of wellknown stress-reactions under the influence of other factors - physical stress, cooling, hypoxia, starvation and others. The principal mechanism of realization of reaction on stress (Selye's general adaptation syndrome; Selye, 1946) is an activation of hypothalamic-pituitaryadrenocortical system, accompanied by an increased flow of catecholamines and glucocorticoids in the blood stream. It provides an increase of the level of oxidative processes, the mobilization of energy to activate the functions of the basic physiological systems. 
An alternative mechanism to protect a body from damaging effects, including radiation, is the hypobiosis or the strategy of tolerance (Kulinskii \& Ol'khovskii, 1992). This strategy is based on the stress-limiting systems of homeostasis regulation, such as serotoninergic, GABA-ergic, causing reduction of aerobic energy metabolism and oxidative processes, transformation of work physiological systems up to minimum level (Lyman et al., 1982; Kalabukhov, 1985; Anufriev \& Akhremenko, 1992; Hochachka \& Somero, 2002). Choice one or another strategy for a particular environment depends on the initial functionally-metabolic condition of organism due to heredity or acquired experience, as well as strength and duration of the affecting factor (Parsons, 1993).

It can be assumed that the established metabolic changes in A. uralensis from the EURT area correspond to stress-realizing strategy of physiological adaptation, which provides through mobilization of hypothalamic-pituitary-adrenocortical system maintenance, especially, high levels of aerobic energy metabolism and cellular-tissue functional activity. In terms of evolution, a more progressive stress-realizing strategy plays a key role in processes of the active exploration of new ecological niches by biota (Markel', 2008). At the same time, excess action of stressor on the organism may lead to development of the stress-induced pathologies and of the accelerated ageing of organism (McEwen, 1998; Parsons, 2003). The more intensive regime of cells functioning than in the control territory, accompanied by structural changes (accumulation of lipids and LPO products, decrease nuclear-cytoplasmic ratio in cells), can be considered as signs of accelerated ageing of A. uralensis within the EURT area (Rasina \& Orekhova, 2009; Orekhova, 2010). The accelerated ageing is particular morphological and functional consequences for the realization of adaptation to unfavorable conditions. In general, the signs of accelerated ageing of cells, tissues and an organism are depend as a whole on environmental radiation factor, as it was indicated in numerous works (Il'enko \& Krapivka, 1998, Mamina, 1998; Materii et al., 2003; Kudyasheva et al., 2004).

The metabolic changes in $M$. rutilus within the EURT area are the consequences of the hypobiotic strategy of physiological adaptation, which is directed to reduction of cellular-tissue functional activity, aerobic energy metabolism, oxidative processes and growth of the plastic potential. The phylogenetically more ancient and evolutionary less progressive hypobiotic strategy determines passive defense mechanisms (or tolerance) of biota at high rate of the damaging effect, while at the same time prevents the development of the diseases and creates the possibility of slowing the aging process and increasing the life time of the organism (Chernilevskii, 1998; Hochachka \& Somero, 2002; Cotton \& Harlow, 2010).

The obtained results show the dependence of the realization of the strategies of physiological adaptation from the initial functionally-metabolic state of organism. The stress-realizing strategy of physiological ad- aptation of $A$. uralensis to the conditions within the EURT is defined by presence of the potential for functional activation, namely, an initially high content of mitochondrial and total proteins in the tissues, as well as a sufficient level of carbohydrates and lipid reserves. The hypobiotic strategy adaptation of $M$. rutilus to the conditions within the EURT is formed, in contrast, on the basis of initial low levels of reserves and high intensity of the cell-tissue systems functioning, caused by specialization of a species to habitat area.

\section{Multivariate comparison of rodent's samples}

An analysis of the matrix of generalized Mahalanobis distances $\left(\mathrm{D}^{2}\right)$ showed the maximal similarity of two samples of $A$. uralensis. The larger distance between the control-EURT samples in M. rutilus comparing with A. uralensis (Fig. 7) indicates a more expressed functional-metabolic shift of the former species under the influence of environmental radioactive contamination. The level of response of two types of organisms is in agreement with the level of accumulation of ${ }^{90} \mathrm{Sr}$ in bone tissue, which determines the radiation absorbed dose and reflects the degree of damaging effects on a body. More expressed metabolic changes for M. rutilus are found consistent with a high level of accumulation of radionuclides (Tab. 1), due to food specialization of this species presented by vegetative parts of herbaceous plants, mosses, lichens and mushrooms, accumulating radionuclides (Il'enko \& Krapivka, 1998). The bigger biochemical shift in M. rutilus within the EURT area relative to $A$. uralensis have been established on the basis of some hematological parameters (Tarahtii \& Kardonina, 1995). This is not consistent with its smaller radiosensitivity to external $\gamma$-radiation $\left(\mathrm{LD}_{50 / 30}\right.$ in Tab. 1) and confirms the differences in the mechanisms of the organism's response to the high and small doses of radiation exposure (Burlakova, 1994).

Different trends of metabolic reactions during the adaptation process of $A$. uralensis and $M$. rutilus to the factor of radiation leads to an increase of interspecies differences in an initial level. However, a largest cluster, combining two species regardless of their habitat (Fig. 7) shows that initial metabolic characteristics formed during the evolution and ecological specialization of species to natural habitat are preserved. Consequently, the level of radiation exposure within the EURT area is not sufficient to change the evolutionary formed features of these species. Genetic markers of inherited changes in the body (microsatellite and allozyme variations) indicate that there is no difference in haplotype of irradiated and control animals (Makova et al., 2000; Modorov \& Pozolotina, 2011), despite the fact that chromosomal abnormalities demonstrate the reaction of the genome of some cells on chronic radiation (Yalkovskaya et al., 2010). The ontogenetic determination of changes in the small mammals within the radioactive areas was substantiated in numerous works (Vasil'ev \& Vasil'eva, 2000; Vasil'ev, 2005; Lyubashevskiy et al., 
2009). The return to initial levels of biochemical parameters in rodents from the EURT area after 45 days of animals staying in vivarium showed an absence of homeostasis stability, formed under environmental radioactive contamination (Orekhova \& Rasina, 2009). It can be assumed that the metabolic changes we have identified are the phenotypic modification, emerging in ontogeny on the basis of an initial genotype.

\section{Conclusion}

The differences of initial biochemical parameters of A. uralensis and M. rutilus were established trapped in the control territory outside the zone of radioactive contamination. The high level of tissue proteins, carbohydrate and lipid reserves in the organism and low level oxidative processes were indicated in $A$. uralensis, in comparison with $M$. rutilus.

The presence of the potential for functional activation of cells and tissues in A. uralensis and its absence in $M$. rutilus is determinant for forming strategy of physiological adaptation in conditions of environmental radioactive contamination: the stress-realizing strategy — in A. uralensis, the hypobiotic strategy — in $M$. rutilus. More expressed functional-metabolic shifts in $M$. rutilus, compared with $A$. uralensis, are in disagreement with a lower radiosensitivity of this species to acute external $\gamma$-radiation, but are combined with a higher level of ${ }^{90} \mathrm{Sr}$ accumulation in bone tissue.

The level of radiation exposure within the EURT area is not sufficient to change the evolutionary formed functional- metabolic features of these species, despite more than hundred generations of habitat of rodent's populations in such conditions. It can be assumed that the changes established in condition of EURT area have the character the phenotypic modifications, taking place at ontogenesis on the basis of an initial genotype.

ACKNOWLEDGEMENTS. We are grateful to our colleagues (Institute of Plant and Animal Ecology of the Ural Branch of Russian Academy of Sciences) for assistance in all phases of work: V.N. Pozolotina, E.B. Grigorkina, V.I. Starichenko, M.V. Modorov, E.M. Karimullina, E.V. Antonova. We appreciate reviewers for valuable consultations and critical remarks. We specially thank A.A. Lissovsky (Zoological Museum of the Moscow State University) for support and professional guidance of editor, the correcting of the English text and for helping in producing the figures.

\section{References}

Aguas A.P., Esaguy N., Grande N., Castro A.P. \& Castelo Branco N.A. 1999. Effect low frequency noise exposure on BALB/c mice splenic lymphocytes // Aviation Space and Environmental Medicine. Vol.70. No.3. P.128-131.

Ahlers I. 1994. Changes in whole-body metabolic parameters associated with radiation // Advances in Space Research. Vol. 14. P.531-539.

Aleksakhin R.M. \& Prister B.S. 2008. [The cradle of national radioecology (to 50-th of Kyshtym accident)] // Radi- atsionnaya Biologiya. Radioekologiya. Vol.48. No.2. P.234-250 [in Russian].

Anufriev A.I. \& Akhremenko A.K. 1992. Dependence of frequency of Citellus undulatus arousal on ambient temperature // Kolaeva S., Popova N., Solomonov N. \& Wang L.C.H. (eds.). Mechanisms of natural hypometabolic states. Pushchino: Pushchino Research Centre. P.31-35.

Asatiani V.S. 1956. [Methods of biochemical research]. Moskva: Medgiz. 461 p. [in Russian]

Banni M., Jebali J., Daubeze M., Clerandau C., Guerbej H., Narbonne J. F. \& Boussetta H. 2005. Monitoring pollution in Tunisian coasts: application of a classification scale based on biochemical markers // Biomarkers. Vol.10. No.2-3. P.105-116.

Bezel V.S. 2006. [Ecological Toxicology: Population and Biocenotic Aspects]. Ekaterinburg: Goshchitskii. 280 p. [in Russian]

Bol'shakov V.N. (ed.) 1990. [Conclusions of the Commission to assess the of ecological situation in the area of the production association «Mayak» Nuclear Power Ministry of the USSR, organized by order of the Presidium of the USSR No 1140-501 on 12/06/1990] // Radiobiologiya. Vol.31. No.3. P.436-452. [in Russian]

Bol'shakov V.N., Koval'chuk L.A. \& Yastrebov A.P. 1984. [The Energy Exchange in Voles and its Changes in Extreme Conditions]. Sverdlovsk: Izdatelstvo UNC USSR. 104 p. [in Russian]

Bol'shakov V.N. \& Moiseenko T.I. 2009. Anthropogenic evolution of animals: facts and their interpretation // Russian Journal of Ecology. Vol.40. No.5. P.323-332.

Borovikov V. 2003. [STATISTICA. Art Analysis of the Data on Computer: for Professionals]. SPb: Izdatel'stvo "Piter". 688 p. [in Russian]

Bradford M.M. 1976. A rapid and sensitive method for the quantitation of microgram quantities of protein utilizing the principal of protein-dye binding // Analytical Biochemistry. Vol.72. P.248-254.

Brodsky V.Y. \& Uryvaeva I.V. 1985. Genome Multiplication in Growth and Development. Biology of Polyploid and Polytene Cells. Cambridge University Press. 305 p.

Burlakova, E.B. 1994. The Effects of Ultra-Low Doses // Herald of the Russian Academy of Science. Vol.64. No.3. P.205-210.

Chernilevskii V.E. 2008. [Hypobiosis problems and prolong life] // Dontsov V.N. (ed.). [Dokladi MOIP. Sektsiya gerontologii]. Moskva: Multiprint. No.41. P.105-123 [in Russian].

Colin M. 1997. Gluconeogenesis and the Peroxisome // Molecular and Cellular Biochemistry. Vol.166. No.1-2. P.159-168.

Cotton C.J. \& Harlow H.J. 2010. Avoidance of skeletal muscle atrophy in spontaneous and facultative hibernators // Physiological and Biochemical Zoology. Vol.83. No.3. P.551-560.

Darenskaya N.G. \& Korotkevich A.O. 2001. [Non-specific Reactivity and Principles of Individual Resistance]. Moskva: Voentekhizdat. 236 p. [in Russian]

Davidson M.B. \& Berliner J.A. 1974. Acute effects of insulin on carbohydrate metabolism in rat liver slices: independence from glucagon // American Journal of Physiology. Vol.227 P.79-87. 
Evtodienko Y.V. \& Teplova V.V. 1996. [The biological significance and mechanisms of the effect Krebti in rapidly proliferating cells. Role of $\mathrm{Ca}^{2+}$ ] // Biokhimiya. Vol.61. No.11. P.1995-2004 [in Russian].

Fedotov V.P. \& Pozdnyakov A.L. 1968. [To a question about the meaning of corticosteroids in realization lympholitic effect of ionizing radiation] // Radiobiologiya. Vol.8. No.2. P.305-307 [in Russian].

Gadzala-Kopciuch R., Berecka B., Bartoszewicz J. \& Buszewski B. 2004. Some considerations about bioindicators in enviromental monitoring // Polish Journal of Environmental Studies. Vol.13. No.5. P.453-462.

Gorban E.N. \& Baraboi V.A. 1999. [Endocrine mechanisms of radiation stress] // Archiv Klinicheskoi and Eksperimental'noi Meditsiny. Vol.8. No.2. P.90-95 [in Russian].

Grigorkina E.B. 2004. [Biological characteristics and ecological factors determining mammalian radioresistance in the Rodentia order] // Radiatsionnaya Biologiya. Radioecologiya. Vol.44. No.3. P.245-250 [in Russian].

Grigor'ev A.U. 1991. [Individual Radiosensitivity]. Moskva: Energoatomizdat. 80 p. [in Russian]

Grigor'ev Y.G., Shafirkin A.V., Nikitina V.N. \& Vasin A.L. 2003. [Remote effects of chronic exposure to ionizing radiation and electromagnetic fields with respect to hygienic standardization] // Radiatsionnaya Biologiya. Radioekologiya. Vol.43. No.5. P.565-578 [in Russian].

Gromov I.M. \& Erbaeva M.A. 1995. [Mammals of Russia and Adjacent Territories. Lagomorphs and Rodents]. Sankt-Peterburg: Izdatel'stvo Zoologicheskogo Instituta Rossiiskoi Akademii Nauk. 521 p. [in Russian]

Guppy M., Greiner E. \& Brand K. 1993. The role of the Crabtree effect and an endogenous fuel in the energy metabolism of resting and proliferating thymocytes // European Journal of Biochemistry. Vol.212. No.1. P.95-99.

Hochachka P. \& Somero G. 2002. Biochemical Adaptation. Mechanism and Process in Physiological Evolution. New York: Oxford University. 467 p.

Il'enko A.I. \& Krapivka T.P. 1989. [Ecology of Animals to Radiation Biogeocoenose]. Moskva: Nauka. 224 p. [in Russian]

Ivanter E.V. 2008. [Mammals of Karelia]. Petrozavodsk: Izdatel'stvo Petrozavodskogo Universiteta. 292 p. [in Russian]

Kalabukhov N.I. 1985. [Hibernation of Mammals]. Moskva: Nauka. 264 p. [in Russian]

Karaseva E.V. \& Telitsina A.Y. 1996. [Methods of Studying Rodents in Field Conditions]. Moskva: Nauka. 227 p. [in Russian]

Kates M. 1975. [Technique Lipidologii]. Moskva: Mir. 322 p. [in Russian]

Kendysh I.P. \& Fedotov V.P. 1967. [On the mechanism of postradiation increase of glycogen to liver of rats] // Radiobiologiya. Vol.7. No.2. P.243-246 [in Russian].

Kim J.O., Myuller K.W. \& Klekko W.R. 1998. [Factor, Discriminant and Cluster Analysis]. Moskva: Finansy i Statistika. 215 p. [in Russian]

Kirillov N.A. \& Smorodchenko A.T. 1999. Histochemical characteristics of lymphoid organs in rats subjected to stress // Bulletin of Experimental Biology and Medicine. Vol.127. No.2. P.171-173.
Kolcheva N.E. 1986. [Dynamics of age structure and population abundance wood mice (Apodemus sylvaticus L.) in the Southern Urals] // Ecologiya. No.6. P.51-58 [in Russian].

Korovkin B.F 1965. [Enzymes in the Diagnosis of Myocardial Infarction]. Leningrad: Meditsina. 128 p. [in Russian]

Koval'chuk L.A. 2008. [Ecologo-physiological Aspects of Adaptation to Condition of Technogenic Ecosystems]. Ekaterinburg: Izdatel'stvo UrO RAN. 215 p. [in Russian]

Koval'chuk L.A. \& Yastrebov A.P. 2003. [Ecological physiology of small mammals in the Urals]. Ekaterinburg: Izdatel'stvo Ural'skogo Universiteta. 184 p. [in Russian]

Krivchenkova R.S. 1977. [Determine the activity of cytochrome oxidase in mitochondria suspension] // Orekhovich V.N. (ed.). Sovremennye Metody v Biokhimii. Moskva: Meditsina. P.47-49 [in Russian].

Kruskal W.H. \& Wallis W.A. 1952. Use of ranks in onecriterion variance analysis. // Journal of the American Statistical Association. Vol. 47. No. 260. P. 583-621.

Kudyasheva A.G., Shishkina L.N., Shevchenko O.G., Bashlykova L.A. \& Zagorskaya N.G. 2004. [Biological Effects of Radioactive Contamination to Populations of Mouse-like Rodents]. Ekaterinburg: Izdatel'stvo Ural'skogo Otdeleniya Rossiiskoi Akademii Nauk. 212 p. [in Russian]

Kulinskii V.I. \& Ol'hovskii I.A. 1992. [Two adaptive strategies in adverse conditions - resistant and tolerant: the role of hormones and receptors] // Uspekhi Sovremennoi Biologii. Vol.112. No.5-6. P.697-714 [in Russian].

Lyubashevskiy N.M., Vasil'ev A.G. \& Starichenko V.I. 2009. [The analysis of the rodents pathology on EURT] // Vestnik Ural'skoi Meditsinskoi Akademicheskoi Nauki. Vol.25. No.2. P.142-143 [in Russian].

Lyman C.P., Willis J.C., Malan A. \& Wang L.C.H. 1982. Hibernation and Torpor in Mammals and Birds. New York, London: Academic Press. 303 p.

Makova K.D., Nekrutenko A. \& Baker R.J. 2000. Evolution of microsatellite alleles in four species of mice (genus Apodemus) // Journal of Molecular Evolution. Vol.51. P.166-172.

Mamina V.P. 1998. [Histological analysis of testes in wood mouse (Apodemus sylvaticus) and the red vole (Clethrionomys rutilus), living in conditions of high radiation background] // Radiatsionnaya Biologiya. Radioecologiya. Vol.38. No.6. P.813-818. [in Russian]

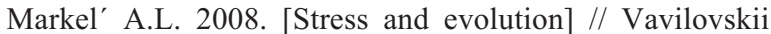
Zhurnal Genetiki i Selektsii. Vol.12. No.1-2. P.206-215 [in Russian].

Marcus L. 1993. Some aspects of multivariate statistics for morphometrics // Contribution to Morphometrics. Madrid: C.S.I.C. P. $98-130$

Materii L.D., Ermakova O.V. \& Taskaev A.I. 2003. [Morphofunctional Evaluation of the State of the Organism of Small Mammals to Radio-ecological Studies (for example, the Root Vole)]. Syktyvkar: Izdatel'stvo Ural'skogo Otdeleniya Rossiiskoi Akademii Nauk. 164 p. [in Russian]

Mazina N.K. 2005. The structure of energy supply for tissue adaptation in small mammals differing in ecological spe- 
cialization // Russian Journal of Ecology. Vol.36. No.6. P.427-434.

McEwen B.C. 1998. Protective and damaging effects of stress mediators // New English Journal of Medicine. Vol.338. P.171-179.

Meerson F.Z. 1963. [The Relationship Between Physiological Function and the Genetic Apparatus of Cells]. Moskva: Izdatel'stvo Akademii Meditsinskikh Nauk. 91 p. [in Russian]

Modorov M.V. \& Pozolotina V.N. 2011. Allosyme variation of the pygmy wood mouse Apodemus uralensis (Rodentia, Muridae) in the Ural region // Russian Journal of Genetics. Vol.47. No.3. P.332-339.

Nikipelov B.V., Romanov G.N. \& Buldakov L.N. 1989. Radiation accident in the South Urals in 1957 and the elimination of its consequences // Recovery Operation in the Event of Nuclear Accident or Radiological Emergency. Vienna: IAEA. P.373-403.

Olenev G.V. 2002. Alternative types of ontogeny of cyclomorphic rodents and their role in population dynamics: ecological analysis // Russian Journal of Ecology. Vol.33. No.5. P.321-330.

Orekhova N.A. 2010. [Analysis of Metabolic Homeostasis of Rodents with Different Ecological Specialization, Living in a Radioactive Environments]. Abstract of Dissertation of Candidate of Biological Sciences. Ekaterinburg. 20 p. [in Russian]

Orekhova N.A. \& Rasina L.N. 2009. [Mechanisms of adaptation processes at Apodemus uralensis in EURT] // Taskaev A.I. (ed.). Biologicheskie Effekty Malykh Doz Ioniziruyushchei Radiatsii i Radioaktivnoe Zagryaznenie Sredy. Syktyvkar: Izdatel'stvo Ural'skogo Otdeleniya Rossiiskoi Akademii Nauk. P.91-93 [in Russian].

Osmundsen H., Bremer J. \& Pedersen J.I. 1991. Metabolic aspects of peroxisomal $\beta$-oxidation // Biochimica et Biophysica Acta (BBA) - Lipids and Lipid Metabolism. Vol.1085. No.2. P.141-158.

Panin L.E. 2006. Lipoprotein metabolism and atherosclerosis // Bulletin of the Siberian Branch of the Russian Academy of Medical Sciences. No.2. P.15-22.

Panin L.E. 2010. Homeostasis and problems of circumpolar health (methodological aspects of adaptation) // Bulletin of the Siberian Branch of the Russian Academy of Medical Sciences. No.3. P.6-11.

Panteleyev P.A. 2010. [Rodentology]. Moskva: Tovarishestvo nauchnikh izdanii KMK. 221 p. [in Russian]

Parsons P.A. 1993. The importance and consequences of stress in living and fossil populations: from life-history variation to evolutionary change // The American Naturalist. Vol.142 (Suppl.). P.5-20.

Parsons P.A. 2003. Energy, stress and the invalid linear nothreshold premise: a generalization illustrated by ionizing radiation // Biogerontology. Vol.4. No.4. P.227-231.

Pavlinov I.Ya. 2003. [The Taxonomy of Recent Mammals] Moskva: Izdatel'stvo Moskovskogo Universiteta. 297 p. [in Russian]

Pokrovskii A.A. \& Malakhova E.A. 1969. [Micro-determination of total nitrogen] // Pokrovsky A.A. (ed.). Biokhimicheskie Metody Issledovaniya v Klinike. Moskva: Meditsina. P.79-81 [in Russian].
Pozolotina V.N., Molchanova I.V., Karavaeva E.N., Mikhailovskaya L.N. \& Antonova E.V. 2008. [Current State of Terrestrial Ecosystems of the Eastern Ural Radioactive Trace: Contamination Levels and Biological Effects]. Ekaterinburg: Goshchitskii. 204 p. [in Russian]

Rasina L.N. \& Orekhova N.A. 2009. [Metabolic homeostasis of small mammals in the Eastern Ural Radioactive Trace] // Radiatsionnaya Biologiya. Radioekologiya. Vol.49. No.2. P.238-245 [in Russian].

Rolland P.H. \& Chambaz E.M. 1977. Effects of prostaglandins on steroidogenesis by bovine adrenal cortex mitochondria // Molecular and Cellular Endocrinology. Vol.7. P.325-333.

Romanova L.A. \& Stal'naya I.D. 1977. [Method for determination of lipid hydroperoxides with ammonium thiocyanate] // Orekhovich V.N. (ed.). Sovremennye Metody v Biokhimii. Moskva: Meditsina. P.65 [in Russian].

Selye H. 1946. The general adaptation syndrome and the diseases of adaptation // Journal of Clinical Endocrinology and Metabolism. No.6. P.117-231.

Shevchenko O.G., Zagorskaya N.G., Kudyasheva A.G. \& Shishkina L.N. 2008. Dependence of response reaction of root voles to low-intensity irradiation on initial state of the tissue antioxidant system // Journal of Evolutionary Biochemistry and Physiology. Vol.44. No.2. P.212-220.

Sneath P.H.A. \& Sokal R.R. 1973. Numerical Taxonomy. San Fransisco: W.N. Frieman. 573 p.

Sokolov V.E., Krivolutskii D.A. \& Usachev V.L. 1989. [Wild Animals in the Global Radioecological Monitoring]. Moskva: Nauka. 150 p. [in Russian]

Spirin A.S. 1958. [Spectrophotometric determination of the total amount of nucleic acids] // Biokhimiya. Vol.23. No.5. P.656-662 [in Russian].

Stal'naya I.D. \& Garishvili T.G. 1977. [Method for determination of malondialdehyde with thiobarbituric acid] // Orekhovich V.N. (ed.). Sovremennye Metody v Biokhimii. Moskva: Meditsina. P.66-68 [in Russian].

Starichenko V.I. 2004. [Strontium-90 in bone tissue of small mammals in the Eastern Ural Radioactive Trace (EURT)] // Rikhvanov L.I. (ed.). Radioaktivnost' i Radioaktivnye Elementy v Srede Obitaniya Cheloveka. Tomsk: Tandem-Art. P.576-579 [in Russian].

Streffer C. 1969. Strahlen-Biochemie. Berlin, Heidelberg, New York: Springer-Verlag. 195 p.

Tarakhtii E.A. \& Kardonina T.L. 1995. [Quantitative morphological study of the blood system of Apodemus uralensis and Myodes rutilus, living on the territory EURT] // Radiatsionnaya Biologiya. Radioekologiya. Vol.35. No.4. P.550-559 [in Russian].

Trudolyubova M.G. 1977. [Quantitative determination of DNA and RNA in subcellular fractions of animal cells] // Orekhovich V.N. (ed.). Sovremennye Metody v Biokhimii. Moskva: Meditsina. P.313-316 [in Russian].

Ushakov I.B., Stemberg A.S. \& Shafikin A.V. 2007. [Reactivity and Resistance of the Organism of Mammals (the Principles of the Formation, Regulation and Forecasting)]. Moskva: Nauka. 493 p. [in Russian]

Vasil'ev A.G. 2005. [Epigenetic Basis of Phenetics: Towards a Population Meronomy]. Ekaterinburg: Izdatel'stvo "Akademkniga". 640 p. [in Russian] 
Vasil'ev A.G. \& Vasil'eva I.A. 2000. [Fenogenetic analysis of long-term effects Totsky nuclear explosion] //Vasil'ev A.G. (ed.). Problemy Otdalennykh Ekologo-geneticheskikh Posledstvii Radiatsionnykh Intsidentov: Totskii Yadernyi Vzryv. Ekaterinburg: Izdatel'stvo UrO RAN. P.123-128 [in Russian].

Vosylienë M.Z. 1999. The effect of heavy metals on haematological indices of fish // Acta Zoologica Lituanica. Vol.9. No.2. P.76-82.

Weiss R.G., Chacko V.P. \& Gerstenblith G. 1989. Fatty acid regulation of glucose metabolism in the intact beating ret heart assessed by carbon-13 NMR spectroscopy the critical role of dehydrogenase // Journal of Molecular and Cellular Cardiology. Vol.21. P.469-478.
Yalkovskaya L.E., Grigorkina E.B. \& Tarasov O.V. 2010. [The cytogenetic consequences of chronic irradiation in rodent populations inhabiting the Eastern Urals radioactive trace zone] // Radiatsionnaya Biologiya. Radioekologiya. Vol.50. No.4. P.466-471 [in Russian].

Zakharov V.M. \& Clark D.M. 1993. [Integral Assessment of Ecosystem Health and Some Species]. Moskva: Moskovskoe otdeleniye Mezhdunarodnogo fonda «Biotest». 68 p. [in Russian]

Zammit V.A. 1981. Regulation of hepatic fatty acid metabolism // Biochemical Journal. Vol.198. P.75-89.

Zolotnitskaya R.P. 1987. [Methods of Hematology] // Menshikov V.V. (ed.). Laboratornye Metody Issledovaniya $\mathrm{v}$ Klinike. Moskva: Meditsina. P.106-145 [in Russian]. 